\title{
Heat of Combustion and Formation of Cyanogen ${ }^{1}$
}

\author{
John W. Knowlton ${ }^{2}$ and Edward J. Prosen
}

\begin{abstract}
Calorimetric measurements were made of the heat of combustion of cyanogen in oxygen in a flame at constant pressure. The data yielded the following value for the reaction of combustion:

$$
\begin{aligned}
\mathrm{C}_{2} \mathrm{~N}_{2}(\text { gas })+2 \mathrm{O}_{2}(\text { gas }) & =2 \mathrm{CO}_{2}(\text { gas })+\mathrm{N}_{2}(\text { gas }) \\
\Delta H c^{\circ} \text { at } 25^{\circ} \mathrm{C} & =-1095.97 \pm 1.80 \mathrm{kj} / \mathrm{mole} \\
& =-261.94 \pm 0.43 \mathrm{kcal} / \mathrm{mole} .
\end{aligned}
$$
\end{abstract}

Utilizing the value for the heat of formation of carbon dioxide, the following value is given for the reaction of formation:

$$
\begin{aligned}
2 \mathrm{C} \text { (solid, graphite) }+\mathrm{N}_{2} \text { (gas) } & =\mathrm{C}_{2} \mathrm{~N}_{2} \text { (gas), } \\
\Delta H f^{\circ} \text { at } 25^{\circ} \mathrm{C} & =308.94 \pm 1.80 \mathrm{kj} / \mathrm{mole} \\
& =73.84 \pm 0.43 \mathrm{kcal} / \mathrm{mole} .
\end{aligned}
$$

\section{Introduction}

This investigation is a continuation of the program of determining the heats of formation of chemical substances. The heat of combustion of cyanogen (gas) was measured because of the discordance in the values for this property given in the literature.

\section{Method and Apparatus}

The calorimetric method and apparatus used in the present investigation have been previously described $[4,5]{ }^{3} \quad$ Platinum resistance thermometer No. 262, 214 and resistance bridge No. 404 were used [6]. White double potentiometer No. 156,585 was used in the electrical energy measurements [4]. The same reaction vessel that was used in determining the heat of formation of water [4] was used in this work.

The unit of energy upon which values reported in this paper are based is the absolute joule, derived from mean solar seconds and absolute ohms and volts, in terms of which certification of standard resistors and cells is made by this Bureau. For conversion to the conventional thermochemical calorie, the following relation is used $[1,2]: 1 \mathrm{cal}=4.1840$ abs j.

All molecular weights used in this paper were calculated from the 1947 table of international atomic weights [3].

1 This investigation was completed in 1941, but the preparation of the results for publication was delayed by the transfer of the senior author to work in the U. S. Bureau of Agricultural and Engineering Chemistry and the U. S. Bureau of Mines. This work formed the basis of a thesis submitted by the senior author to the Faculty of the Graduate School of the University of Maryland in partial fulfillment of the requirements for the degree of Doctor of Philosophy.

2 Deceased.

3 Figures in brackets indicate the literature references at the end of this paper.

\section{Chemical Procedure}

\section{Preparation and Purity of the Materials}

The cyanogen was prepared by a method similar to that of Cook and Robinson [7] as described by Ruehrwein and Giauque [8]. This method consisted of precipitating silver cyanide from a saturated aqueous solution of silver nitrate by addition of a slight excess of a 78-percent aqueous solution of potassium cyanide. The silver cyanide was filtered, washed free of excess potassium cyanide, and dried in an oven at $130^{\circ} \mathrm{C}$ for $15 \mathrm{hrs}$. It was then transferred to a 3-liter flask, evacuated to $10^{-5} \mathrm{~mm}$ of mercury and then slowly heated to $380^{\circ} \mathrm{C}$ to drive off cyanogen. About $350 \mathrm{ml}$ of liquid cyanogen was collected.

The sample was degassed and then distilled in a 1-m vacuum-jacketed distillation column packed with glass helices. The condenser temperature was kept constant at $-24.0^{\circ} \mathrm{C}$. A reflux ratio of 10 to 1 was used and the take-off rate maintained at $30 \mathrm{ml} / \mathrm{hr}$. The first fraction of $50 \mathrm{ml}$ and residue of $45 \mathrm{ml}$ were discarded and the two middle fractions of $120 \mathrm{ml}$ each were combined and stored in a 1-liter brass bottle for use in this investigation. Three 5-ml samples, taken after the first fraction, between the middle fractions and after the middle fractions, were used to get an indication of the purity of the cyanogen. Differential vapor-pressure measurements were made on these 5-ml samples according to the method of Shepherd [8], but not using the micrometric-reading devices used by him. The observed differences in vapor pressures of these samples taken over the temperature range of $-24.8^{\circ}$ to $-23.3^{\circ} \mathrm{C}$ were 0.0 $\pm 0.5 \mathrm{~mm}$, indicating that the sample was probably sufficiently pure for this investigation. The cyanogen prepared by Ruehrwein and Giauque [9], utilizing this same procedure except that they passed their 
cyanogen through phosphorus pentoxide as it was generated, was found by them to have a purity of 99.995 mole percent.

To test the effect of cyanogen on the materials with which it would be in contact, a small amount of cyanogen was placed in a glass bulb containing pieces of copper, brass, and steel as well as a smear of stopcock grease. No effect on the materials was observed after 10 months of storage.

The oxygen (prepared commercially from liquid air) used for the combustion was freed of combustible impurities by passage through a tube containing copper oxide at $600^{\circ} \mathrm{C}$. It was then freed of carbon dioxide and water by passage successively through tubes containing ascarite, magnesium perchlorate, and phosphorus pentoxide.

\section{Purity of the Combustion Reaction}

The cyanogen was dried by passage through anhydrous calcium sulfate and was burned in an atmosphere of the purified oxygen in the calorimeter reaction vessel. The combustion was initiated by passing an electric spark across the ends of platinum wires at the tip of the burner. The flame burned quietly in the reaction chamber.

The main products of combustion of cyanogen are carbon dioxide and nitrogen. Other possible products are the oxides of nitrogen, carbon monoxide, carbon, and unburned cyanogen.

No significant deposit of carbon was observed in the reaction vessel after about 50 ignitions of the cyanogen, with combustions of varying duration, including those of the calorimetric observations.

Because nitrous oxide itself supports combustion and since the combustion of cyanogen occurred in a flame in the presence of about 50 percent excess oxygen, the possibility of the presence of nitrous oxide as a combustion product appeared to be very remote. The other oxides of nitrogen are acidic, and, mixed with oxygen, are completely absorbed in alkaline solutions. Nitric oxide will oxidize under these conditions [10]. Tests were made by passing the effluent gas from the combustion of cyanogen in the calorimetric reaction vessel through a solution of sodium hydroxide and determining (see below) the total nitrogen in the solution. Fixed nitrogen was found in amounts varying up to 2 percent of the total nitrogen in the cyanogen burned. Attempts to reduce this amount by varying the flame velocity of the combustion, by changing the technic of ignition, or by use of the reaction vessel used in the experiments on ethane [11] were unsuccessful, or gave difficulty in securing ignition.

Saturation of the oxygen used for combustion with water vapor at $0^{\circ} \mathrm{C}$, as was done by von Wartenberg and Schutza [12], reduced the amount of fixed nitrogen to about 80 percent of its previous amount, and this technique was used in one of the series of calorimetric combustion experiments reported here. Since these amounts of nitrogen oxides were appreciable, it was necessary to determine the amounts quantitatively for each calorimetric experiment.
In the actual calorimetric combustion experiments, the effluent gas from the calorimetric reaction vessel was passed through a U-tube packed successively with ascarite, magnesium perchlorate, and phosphorus pentoxide, separated by layers of dry, acid-washed asbestos fibers. This tube absorbed all of the carbon dioxide, water, oxides of nitrogen, and unburned cyanogen issuing from the calorimeter. The complete absorption of the oxides of nitrogen was verified in a test combustion experiment of cyanogen run for 4 min under the same conditions as in the calorimetric experiments. The gas issuing from the ascarite tube was bubbled into a 10-percent sodium hydroxide solution. No fixed nitrogen was detected in this solution in a test that would have shown the presence of less than $0.01 \mathrm{mg}$. The complete absorption of any unburned cyanogen was verified by passing cyanogen directly into the ascarite tube. No effluent gas was observed when as much as $0.04 \mathrm{~g}$ of cyanogen was passed into the tube.

The determination of the products of combustion was made as follows: After a combustion, the ascarite tube was weighed, the stopcocks were removed, and the stopcock grease carefully removed with ether. The layers of phosphorus pentoxide and magnesium perchlorate were removed, and the traces adhering to the glass were washed out with a jet of distilled water in a manner such as to avoid wetting the ascarite. The asbestos plug over the ascarite was removed and the ascarite dissolved in water. This solution was filtered and diluted to $200 \mathrm{ml}$ in a volumetric flask. From this solution $100 \mathrm{ml}$ was pipetted out for the nitrite determination, and the remainder was used for the determination of total nitrogen. The amount of nitrate was obtained as the difference between the total nitrogen and the nitrite. Thus, by determining both nitrite and nitrate, more information is obtained on the oxides of nitrogen formed than if only total nitrogen had been determined.

For the titration of nitrite, $30 \mathrm{ml}$ of 0.017 molar potassium permanganate was added from a burette to an Erlenmeyer flask. This was diluted to $75 \mathrm{ml}$ with water, and $25 \mathrm{ml}$ of $18 \mathrm{~N}$ sulfuric acid was added. The 100-ml sample was added to this with the flask cooled in tap water. This cold solution was then treated with 0.04-molar sodium oxalate until decolorized, a definite amount of oxalate being added. The end point of the titration was reached by further addition of the permanganate, with the solution heated to $50^{\circ}$ to $60^{\circ} \mathrm{C}$ before addition of the last few drops. For each determination the permanganate equivalent of the oxalate was determined in the same manner. The oxalate was used as the primary standard, with 1 mole of oxalate equivalent to 1 mole of nitrite.

For determination of total fixed nitrogen, the remaining alkaline solution from the ascarite was reduced for $1 \mathrm{hr}$ with $2 \mathrm{~g}$ of Devarda's alloy in a Kjeldahl still, and then the ammonia was distilled into $50 \mathrm{ml}$ of $0.05 \mathrm{~N}$ sulfuric acid, which was backtitrated with $0.05 N$ sodium hydroxide. 
Control tests were performed in which known amounts of sodium nitrite and sodium nitrate were added to the ascarite. The results indicated that the method was sufficiently accurate for this investigation.

It was also shown in a control test that unburned cyanogen absorbed by the ascarite had no effect on the fixed nitrogen or nitrite determinations.

To determine any carbon monoxide formed in the combustion, the effluent gas from the ascarite tube was passed through a tube packed with copper oxide and maintained at about $600^{\circ} \mathrm{C}$, then through a second ascarite tube packed in the same manner as the first ascarite tube. In this way, any carbon monoxide formed in the combustion was oxidized to carbon dioxide by passage through the hot copper oxide tube and was weighed as carbon dioxide in the second ascarite tube. It has been previously shown that no oxides of nitrogen nor unburned cyanogen passed through the first ascarite tube. Also, tests for nitrogen on the ascarite in the second tube gave negative results. In the series of calorimetric combustion experiments in which dry oxygen was used for combustion, it was found that an average of 3.5 percent of the total carbon in the cyanogen burned to carbon monoxide. In the series of calorimetric combustion experiments in which watercarrying oxygen was used for combustion, an average of 0.35 percent was formed. The amount of carbon monoxide was determined in the above manner for each calorimetric combustion experiment.

It was to be expected that some cyanogen would pass through the calorimetric reaction vessel unburned during the process of ignition and extinction of the flame. This amount of cyanogen had to be determined since it would be absorbed in the first ascarite tube and the increase in mass of this tube was used to determine the amount of reaction (see below). This amount of cyanogen was deduced from a series of eight separate experiments carried out calorimetrically under the same conditions as in the main calorimetric combustion experiments, but with extinction of the flame immediately following ignition. The average amount of cyanogen burned in these experiments was $0.0077 \mathrm{~g}$. The increase in mass of the ascarite tube was considered to be due to absorption of carbon dioxide and unburned cvanogen. From the temperature rise of the calorimeter, together with its electrical energy equivalent, the total energy evolved in each experiment was calculated. From this total energy was subtracted the energy of sparking (see below) to give the energy due to combustion of cyanogen. The mass of carbon dioxide, corresponding to this quantity of energy, which would have been formed in the pure combustion of cyanogen was calculated, using the approximate value of $1096 \mathrm{kj} /$ mole for the heat of combustion of cyanogen. This mass of carbon dioxide was subtracted from the increase in mass of the ascarite tube to give the mass of unburned cyanogen. The average mass of unburned cyanogen was found to be $0.01730 \mathrm{~g}$ (standard deviation of $0.00013 \mathrm{~g}$ ).

\section{Determination of the Amount of Reaction}

The amount of reaction was determined from the mass of carbon dioxide formed in the combustion. To the increase in mass of the first ascarite absorption tube connected directly to the outlet of the reaction vessel (which absorbed all the carbon dioxide, water, oxides of nitrogen, and unburned cyanogen issuing from the calorimeter), there was added the increase in mass of the second ascarite tube, which was connected to the first through the copper oxide combustion tube (and which absorbed the carbon dioxide formed by oxidation of the carbon monoxide). From this were subtracted the masses of nitrogen oxides as determined from the nitrogen analyses (present as nitrite and nitrate and calculated as nitrogen trioxide, $\mathrm{N}_{2} \mathrm{O}_{3}$, and nitrogen pentoxide, $\mathrm{N}_{2} \mathrm{O}_{5}$, respectively), the average mass of unburned cyanogen $(0.01730 \mathrm{~g})$, and the average mass of water introduced in the experiments using watercarrying oxygen. This result gave the total mass of carbon dioxide representing the amount of reaction. One mole $(44.010 \mathrm{~g})$ of carbon dioxide was taken as equivalent to $1 / 2$ mole of cyanogen.

The average mass of water introduced in the experiments in which the oxygen used for combustion was saturated with water at $0^{\circ} \mathrm{C}$ was determined in 10 separate experiments. In these experiments, water-carrying oxygen was passed through the reaction vessel and absorption tube at the same rate and for the same length of time $(46 \mathrm{~min})$ as was used in the average combustion experiment. The average amount of water absorbed was $0.05234 \mathrm{~g}$ (standard deviation $0.00137 \mathrm{~g})$. An uncertainty of $0.0014 \mathrm{~g}$ of water would cause an uncertainty of \pm 0.029 percent in the determination of the amount of reaction by the above method.

\section{Calorimetric Procedure}

\section{Electrical Energy Experiments}

The results of the experiments to determine the electrical energy equivalent of the calorimeter system are given in table 1 . There are listed: $\Delta R_{c}$, which is the increase in temperature of the calorimeter system corrected for thermal leakage and heat of stirring [4] and expressed as an increase in resistance in ohms of the given platinum thermometer, as measured with the given resistance bridge; the total electrical energy added to the calorimeter system expressed in absolute joules; and the electrical energy equivalent of the calorimeter system, corrected to the standard amount $(3600.00 \mathrm{~g})$ of water in the calorimeter can. The average temperature of the calorimeter was $25.00^{\circ} \pm 0.01^{\circ} \mathrm{C}$ in all experiments. The voltage across the heater was about $40 \mathrm{v}$, the resistance of the heater was about $60 \mathrm{ohms}$, and the time of heating was $2280.00 \mathrm{sec}$ in each experiment. 
TABLE 1. Results of the electrical calibration experiments

\begin{tabular}{|c|c|c|c|c|}
\hline $\begin{array}{l}\text { Exper- } \\
\text { iment } \\
\text { No. }\end{array}$ & $\Delta R_{c}$ & $\begin{array}{c}\text { Electrical } \\
\text { energy }\end{array}$ & $\begin{array}{c}\text { Electrical } \\
\text { energy } \\
\text { equiva- } \\
\text { lent a }\end{array}$ & $\begin{array}{l}\text { Deviation } \\
\text { from } \\
\text { mean }\end{array}$ \\
\hline $\begin{array}{l}1--. \\
2--- \\
3--- \\
4--. \\
5--- \\
6--- \\
7-\ldots \\
8--- \\
9-- \\
10-\end{array}$ & $\begin{array}{r}\text { ohm } \\
0.382549 \\
.378535 \\
.384131 \\
.377548 \\
.377000 \\
.377564 \\
.383307 \\
.380830 \\
.379640 \\
.379085\end{array}$ & $\begin{array}{c}j \\
58345.2 \\
57752.6 \\
58600.2 \\
57650.2 \\
57443.9 \\
57471.3 \\
58398.7 \\
58054.7 \\
57948.5 \\
57789.5\end{array}$ & $\begin{array}{c}j / \text { ohm } \\
152409.2 \\
152409.2 \\
152392.7 \\
152384.3 \\
152383.1 \\
152375.1 \\
152381.4 \\
152462.5 \\
152460.5 \\
152433.9\end{array}$ & $\begin{array}{r}j / 0 h m \\
0.0 \\
-16.0 \\
-24.9 \\
-26.1 \\
-34.1 \\
-27.8 \\
+53.3 \\
+51.3 \\
+24.7\end{array}$ \\
\hline \multicolumn{3}{|c|}{$\begin{array}{l}\text { Mean } \\
\text { Standard deviation of the } \\
\text { mean }\end{array}$} & $\begin{array}{r}152409.2 \\
\pm 10.3\end{array}$ & \\
\hline
\end{tabular}

a Corrected to the standard amount of water in the calorimeter can.

\section{Correction Experiments}

The spark energy was determined calorimetrically in five separate experiments in which only sparking energy was supplied to the calorimeter with oxygen in the reaction vessel. The average value of the sparking energy was found to be $2.07 \mathrm{j} / \mathrm{sec}$ (standard deviation $0.02 \mathrm{j} / \mathrm{sec})$.
The gas energy, column 3 of table 2, was calculated from the known heat capacities of the gases, and the difference between their temperature (taken as that of the air near the tubes leading to the reaction vessel) and the average temperature, with respect to time, of the calorimeter. For this purpose, the heat capacities of oxygen and cyanogen were taken as 29.2 and $44.6 \mathrm{j} /$ degree-mole, respectively [13].

No correction was made for the heat capacities of the effluent gases from the calorimeter, since their average temperature was substantially $25^{\circ} \mathrm{C}$.

\section{Combustion Experiments}

The data of ten calorimetric combustion experiments on cyanogen using dry oxygen for combustion are given in table 2. The net reaction energy is the energy evolved in the experiment after subtracting the gas energy and spark energy. The energy evolved was calculated from the corrected temperature rise, $\Delta R_{c}$, combined with the electrical energy equivalent of the standard calorimeter system. Correction was made for deviations from the standard calorimeter system due to small variations in the amount of water in the calorimeter can in the individual experiments.

TABLE 2. Results of the calorimetric combustion experiments on cyanogen, using dry oxygen for combustion

\begin{tabular}{|c|c|c|c|c|c|c|c|c|c|}
\hline $\begin{array}{l}\text { Experi- } \\
\text { ment } \\
\text { No. }\end{array}$ & $\Delta R_{c}$ & $\begin{array}{c}\text { Gas } \\
\text { energy }\end{array}$ & $\begin{array}{l}\text { Spark } \\
\text { energy }\end{array}$ & $\begin{array}{c}\text { Net reaction } \\
\text { energy }\end{array}$ & $\begin{array}{c}\text { Increase in } \\
\text { mass of } \mathrm{CO}_{2} \\
\text { absorber }\end{array}$ & $\begin{array}{l}\text { Mass of } \\
\mathrm{N}_{2} \mathrm{O}_{3} \mathrm{~b}\end{array}$ & $\begin{array}{l}\text { Mass of } \\
\mathrm{N}_{2} \mathrm{O}_{5}{ }^{\circ}\end{array}$ & $\begin{array}{l}\text { Mass of } \mathrm{CO}_{2} \\
\text { from oxida- } \\
\text { tion of } \mathrm{CO}\end{array}$ & $\begin{array}{c}\text { Mass of } \\
\mathrm{CO}_{2} \mathrm{~d}^{\mathrm{d}}\end{array}$ \\
\hline $\begin{array}{l}1 \\
2 \\
3 \\
4 \\
5\end{array}$ & $\begin{array}{c}\text { ohm } \\
0.383666 \\
.382970 \\
.380896 \\
.381872 \\
.383056\end{array}$ & $\begin{aligned} & j \\
&+ 75.0 \\
&+ 60.0 \\
&+ 41.4 \\
&+4.2 \\
&+4.2\end{aligned}$ & $\begin{array}{c}j \\
31.1 \\
24.8 \\
31.1 \\
31.1 \\
31.1\end{array}$ & $\begin{array}{c}j \\
58498.3 \\
58420.5 \\
58007.3 \\
58267.5 \\
58396.3\end{array}$ & $\begin{array}{c}g \\
4.81255 \\
4.79388 \\
4.75634 \\
4.76104 \\
4.76184\end{array}$ & $\begin{array}{r}g \\
0.16627 \\
.10122 \\
.09973 \\
.10314 \\
.10472\end{array}$ & $\begin{array}{c}g \\
0.01625 \\
.02501 \\
.03094 \\
.02286 \\
.01838\end{array}$ & $\begin{array}{r}g \\
0.10282 \\
.12208 \\
.13195 \\
.15484 \\
.17722\end{array}$ & $\begin{array}{l}g \\
\text { 4. } 77555 \\
4.77243 \\
4.74032 \\
4.77258 \\
4.79866\end{array}$ \\
\hline $\begin{array}{r}6 \\
7 \\
8 \\
9 \\
10\end{array}$ & $\begin{array}{l}.382349 \\
.378938 \\
.384659 \\
383746 \\
.383426\end{array}$ & $\begin{array}{r}+6.8 \\
-0.2 \\
+23.1 \\
+36.6 \\
+2.8\end{array}$ & $\begin{array}{l}31.1 \\
43.5 \\
35.2 \\
37.3 \\
31.1\end{array}$ & $\begin{array}{l}58327.9 \\
57802.3 \\
58683.4 \\
58455.1 \\
58 \times 11.8\end{array}$ & $\begin{array}{l}\text { 4. } 75512 \\
\text { 4. } 69471 \\
4.78875 \\
4.76750 \\
4.75058\end{array}$ & $\begin{array}{l}.10551 \\
.11111 \\
.10226 \\
.10283 \\
.10125\end{array}$ & $\begin{array}{l}.01708 \\
.02329 \\
.02074 \\
.02126 \\
.01401\end{array}$ & $\begin{array}{l}.18244 \\
.23014 \\
.16941 \\
.19413 \\
.19512\end{array}$ & $\begin{array}{l}4.79767 \\
4.77315 \\
4.81786 \\
4.82024 \\
4.81314\end{array}$ \\
\hline
\end{tabular}

a Corrected for deviations from the standard calorimeter system.

b Calculated from the amount of nitrite determined.

- Calculated from the amount of nitrate determined.

$\mathrm{d}$ Corrected for the average mass $(0.01730 \mathrm{~g})$ of unburned cyanogen absorbed in the ascarite.

TABLE 3. Results of the calorimetric combustion experiments on cyanogen, using for combustion oxygen saturated with water at $0^{\circ} C^{\prime}$

\begin{tabular}{|c|c|c|c|c|c|c|c|c|c|}
\hline $\begin{array}{c}\text { Experi- } \\
\text { ment } \\
\text { No. }\end{array}$ & $\Delta R_{c}$ & $\begin{array}{c}\text { Gas } \\
\text { energy }\end{array}$ & $\begin{array}{l}\text { Spark } \\
\text { energy }\end{array}$ & $\begin{array}{c}\text { Net reaction } \\
\text { energy a }\end{array}$ & $\begin{array}{l}\text { Increase in } \\
\text { mass of } \mathrm{CO}_{2} \\
\text { absorber }\end{array}$ & $\begin{array}{l}\text { Mass of } \\
\mathrm{N}_{2} \mathrm{O}_{3} \text { b }\end{array}$ & $\begin{array}{l}\text { Mass of } \\
\mathrm{N}_{2} \mathrm{O}_{5}{ }^{\circ}\end{array}$ & $\begin{array}{l}\text { Mass of } \mathrm{CO}_{2} \\
\text { from oxida- } \\
\text { tion of } \mathrm{CO}\end{array}$ & $\begin{array}{c}\text { Mass of } \\
\mathrm{CO}_{2} \mathrm{~d}\end{array}$ \\
\hline $\begin{array}{l}1 \\
2 \\
3 \\
4 \\
5 \\
6 \\
7\end{array}$ & $\begin{array}{c}\text { ohm } \\
0.382716 \\
.382845 \\
.381556 \\
.382939 \\
.379281 \\
.383901 \\
.380292\end{array}$ & $\begin{array}{r}j \\
-0.1 \\
+3.1 \\
+7.5 \\
+15.8 \\
+12.2 \\
+0.9 \\
+2.8\end{array}$ & $\begin{array}{l}31.1 \\
62.1 \\
31.1 \\
31.1 \\
35.2 \\
31.1 \\
31.1\end{array}$ & $\begin{array}{c}j \\
58418.8 \\
58391.7 \\
58209.7 \\
58291.1 \\
57795.3 \\
58623.1 \\
58051.0\end{array}$ & $\begin{array}{c}g \\
4.86608 \\
4.84746 \\
4.82374 \\
4.85884 \\
4.83108 \\
4.89462 \\
4.85285\end{array}$ & $\begin{array}{c}g \\
0.09602 \\
.07675 \\
.07666 \\
.09560 \\
.10390 \\
.09928 \\
.10204\end{array}$ & $\begin{array}{c}g \\
0.01884 \\
.01986 \\
.01161 \\
.02188 \\
.01802 \\
.02536 \\
.01835\end{array}$ & $\begin{array}{c}q \\
0.01558 \\
.01756 \\
.02394 \\
.01706 \\
.01374 \\
.01531 \\
.01368\end{array}$ & $\begin{array}{c}g \\
\text { 4. } 70399 \\
\text { 4. } 70787 \\
\text { 4. } 70115 \\
\text { 4. } 69674 \\
\text { 4. } 65440 \\
\text { 4. } 72361 \\
\text { 4. } 67650\end{array}$ \\
\hline
\end{tabular}

a Corrected for deviations from the standard calorimeter system.

b Calculated from the amount of nitrite determined.

- Calculated from the amount of nitrate determined.

d Corrected for the average mass of unburned cyanogen and of water absorbed in the ascarite. 
The data of seven calorimetric combustion experiments on cyanogen, using oxygen saturated with water at $0^{\circ} \mathrm{C}$, are given in table 3 . In those experiments for which the time of flow of the watercarrying oxygen differed from $46 \mathrm{~min}$, the amount of water absorbed was calculated from the average value of $0.05234 \mathrm{~g}$ for $46 \mathrm{~min}$ and assuming the amount to vary linearly with the time.

\section{Results}

For the final calculation of the heat of combustion of cyanogen, it is necessary to identify the particular oxides of nitrogen formed in the colorimeter during the combustion in order that appropriate corrections for their respective heats of formation may be applied to the calorimetric observations. For this purpose there must be considered nitric oxide, nitrogen dioxide (in equilibrium with its dimer, nitrogen tetroxide), nitrogen trioxide, and nitrogen pentoxide, as well as nitric acid vapor in the case of the experiments in which water vapor was present in the reaction chamber.

Nitrogen pentoxide is known to decompose completely at $25^{\circ} \mathrm{C}[10, \mathrm{p} .552]$. The dissociation of nitrogen trioxide into nitric oxide and nitrogen dioxide is also virtually complete $[10, p .449]$ under the conditions of the present experiments. This is corroborated by a calculation based on the equilibrium data of Verhoek and Daniels [14]. The fraction of nitrogen tetroxide in equilibrium with nitrogen dioxide, computed from the data of Giauque and Kemp [15], was found to be negligible under the conditions of the present experiments.

It thus appears that the oxides of nitrogen in the effluent gas from the reaction vessel were nitric oxide and nitrogen dioxide. Concerning the absorption by solid alkali (or ascarite) of these substances, Mellor reports the following: (1) nitric oxide reacts with solid potassium hydroxide in the presence of excess oxygen, to form mainly potassium nitrite, but that some nitrate is formed as well [10, p. 432]; (2) nitrogen dioxide should react with solid alkali to give equimolal amounts of nitrite and nitrate, but that larger amounts of nitrate may be formed [10, p. 539-40]; and (3) nitric oxide and nitrogen dioxide in equimolal amounts are absorbed by alkali as pure nitrite. Burdick and Freed [16] state that the assumption that these absorptions of nitrogen oxides are pure reactions is subject to some qualifications.

A reasonable interpretation of the process occurring in the calorimeter with respect to the fixation of nitrogen during the combustion of cyanogen, is that both nitric oxide and nitrogen dioxide are formed in the amounts $x$ moles and $y$ moles, respectively;

$$
\begin{gathered}
x\left[1 / 2 \mathrm{~N}_{2}(g)+1 / 2 \mathrm{O}_{2}(g)=\mathrm{NO}(g)\right], \\
y\left[1 / 2 \mathrm{~N}_{2}(g)+\mathrm{O}_{2}(g)=\mathrm{NO}_{2}(g)\right] .
\end{gathered}
$$

The subsequent reaction of these oxides with ascarite is assumed to take place according to the following reactions

$$
\begin{gathered}
x\left[\mathrm{NO}(g)+\mathrm{NO}_{2}(g)+\right. \\
\left.2 \mathrm{NaOH}(s)=2 \mathrm{NaNO}_{2}(s)+\mathrm{H}_{2} \mathrm{O}(s)\right] \\
y-x\left[\mathrm{NO}_{2}(g)+\mathrm{NaOH}(s)=1 / 2 \mathrm{NaNO}_{2}(\mathrm{~s})+1 / 2 \mathrm{NaNO}_{3}(s)\right. \\
\left.+1 / 2 \mathrm{H}_{2} \mathrm{O}(s)\right]
\end{gathered}
$$

Letting $a$ and $b$ represent the number of moles of nitrite and nitrate determined, respectively, then the amounts of nitric oxide and nitrogen dioxide formed are

$$
\begin{aligned}
& x=1 / 2(a-b), \\
& y=1 / 2(a+3 b) .
\end{aligned}
$$

In the series of experiments in which water vapor was present in the reaction chamber, it was assumed that nitric oxide, nitrogen dioxide, and nitric acid vapor were formed and that the nitric oxide and nitrogen dioxide were present in equimolal quantities $x^{\prime}$ and the nitric acid in quantity $y^{\prime}$ :

$$
\begin{aligned}
& x^{\prime}\left[\frac{1}{2} \mathrm{~N}_{2}(g)+\frac{1}{2} \mathrm{O}_{2}(g)=\mathrm{NO}(g)\right], \\
& x^{\prime}\left[1 / 2 \mathrm{~N}_{2}(g)+\mathrm{O}_{2}(g)=\mathrm{NO}_{2}(g)\right], \\
& y^{\prime}\left[1 / 2 \mathrm{~N}_{2}(g)+5 / 4 \mathrm{O}_{2}(g)+\frac{1}{2} \mathrm{H}_{2} \mathrm{O}(g)=\mathrm{HNO}_{3}(g)\right] .
\end{aligned}
$$

The subsequent reactions with ascarite are assumed to be

$$
\begin{gathered}
x^{\prime}\left[\mathrm{NO}(g)+\mathrm{NO}_{2}(g)+2 \mathrm{NaOH}(s)=2 \mathrm{NaNO}_{2}(s)+\right. \\
\left.\mathrm{H}_{2} \mathrm{O}(s)\right], \\
y^{\prime}\left[\mathrm{HNO}_{3}(g)+\mathrm{NaOH}(s)=\mathrm{NaNO}_{3}(s)+\mathrm{H}_{2} \mathrm{O}(s)\right] .
\end{gathered}
$$

Thus, the amounts of nitric oxide, $x^{\prime}$, nitrogen dioxide, $x^{\prime}$, and nitric acid vapor, $y^{\prime}$, formed are

$$
\begin{aligned}
& x^{\prime}=1 / 2 a \\
& y^{\prime}=b,
\end{aligned}
$$

where $a$ and $b$ represent the number of moles of nitrite and nitrate determined, respectively.

The calorimetric data given in tables 2 and 3 were reduced on the basis of these assumptions and are presented in tables 4 and 5, respectively.

The heats of reactions (1), (2), and (9) were taken as $\Delta H^{\circ}=90.37,33.85$, and $-12.85 \mathrm{kj} / \mathrm{mole}[2]$ and the heat of combustion of carbon monoxide was taken as $\Delta H c^{\circ}=-282.99 \mathrm{kj} / \mathrm{mole}[2]$.

It is recognized that, in this work, there remains an uncertainty in the actual composition of the effluent gas from the calorimeter. Cognizance of this was taken in estimating the over-all uncertainty in the heat of combustion. 
TABLE 4. Calculation of the heat of combustion of cyanogen from the data of table 2 in which dry oxygen was used for combustion

\begin{tabular}{|c|c|c|c|c|c|c|c|c|c|c|}
\hline $\begin{array}{l}\text { Experi- } \\
\text { ment } \\
\text { No. }\end{array}$ & $\begin{array}{l}\text { Amount } \\
\text { of NO } \\
\text { formed }\end{array}$ & $\begin{array}{l}\text { Amount } \\
\text { of } \mathrm{NO}_{2} \\
\text { formed }^{\mathrm{a}}\end{array}$ & $\begin{array}{l}\text { Amount } \\
\text { of CO } \\
\text { formed }\end{array}$ & $\begin{array}{l}\text { Correction } \\
\text { for NO }\end{array}$ & $\begin{array}{c}\text { Correc- } \\
\text { tion } \\
\text { for } \mathrm{NO}_{2}\end{array}$ & $\begin{array}{c}\text { Correc- } \\
\text { tion } \\
\text { for } \mathrm{CO}\end{array}$ & $\begin{array}{l}\text { Corrected } \\
\text { reaction } \\
\text { energy }\end{array}$ & $\begin{array}{l}\text { Amount } \\
\text { of } \mathrm{C}_{2} \mathrm{~N}_{2} \\
\text { burned }\end{array}$ & $\begin{array}{c}\text { Heat of } \\
\text { combustion } \\
\text { at } 25^{\circ} \mathrm{C}\end{array}$ & $\begin{array}{l}\text { Devia- } \\
\text { tion from } \\
\text { mean }\end{array}$ \\
\hline $\begin{array}{l}1 \\
2 \\
3 \\
4 \\
5\end{array}$ & $\begin{array}{c}\text { Moles } \\
0.0012476 \\
.0011000 \\
.0010255 \\
.0011452 \\
.0012075\end{array}$ & $\begin{array}{c}\text { Moles } \\
0.0018494 \\
.0020262 \\
.0021713 \\
.0019918 \\
.0018881\end{array}$ & $\begin{array}{c}\text { Moles } \\
0.0023363 \\
.0027739 \\
.0029982 \\
.0035183 \\
.0040268\end{array}$ & $\begin{array}{r}j \\
112.7 \\
99.4 \\
92.7 \\
103.5 \\
109.1\end{array}$ & $\begin{array}{c}j \\
62.6 \\
68.6 \\
73.5 \\
67.4 \\
63.9\end{array}$ & $\begin{array}{r}j \\
661.1 \\
785.0 \\
848.5 \\
995.6 \\
1139.5\end{array}$ & $\begin{array}{c}j \\
59334.7 \\
59373.5 \\
59022.0 \\
59434.0 \\
59708.8\end{array}$ & $\begin{array}{c}\text { Moles } \\
0.0542553 \\
.0542198 \\
.0538550 \\
.0542215 \\
.0545178\end{array}$ & $\begin{array}{l}\text { kj/mole } \\
1093.62 \\
1095.05 \\
1095.94 \\
1096.13 \\
1095.22\end{array}$ & $\begin{array}{r}\text { kj/mole } \\
-1.38 \\
+0.05 \\
+.94 \\
+1.13 \\
+0.22\end{array}$ \\
\hline $\begin{array}{r}6 \\
7 \\
8 \\
9 \\
10\end{array}$ & $\begin{array}{l}.0012299 \\
.0012461 \\
.0011533 \\
.0011560 \\
.0012023\end{array}$ & $\begin{array}{l}.0018623 \\
.0021085 \\
.0019213 \\
.0019432 \\
.0017211\end{array}$ & $\begin{array}{l}.0041454 \\
.0052293 \\
.0038494 \\
.0044110 \\
.0044335\end{array}$ & $\begin{array}{l}111.1 \\
112.6 \\
104.2 \\
104.5 \\
108.7\end{array}$ & $\begin{array}{l}63.0 \\
71.4 \\
65.0 \\
65.8 \\
58.3\end{array}$ & $\begin{array}{l}1173.1 \\
1479.8 \\
1089.3 \\
1248.3 \\
1254.6\end{array}$ & $\begin{array}{l}59675.1 \\
59466.1 \\
59941.9 \\
59873.7 \\
59833.4\end{array}$ & $\begin{array}{l}.0545066 \\
.0542280 \\
.0547360 \\
.0547630 \\
.0546823\end{array}$ & $\begin{array}{l}1094.82 \\
1096.59 \\
1095.11 \\
1093.32 \\
1094.20\end{array}$ & $\begin{array}{l}-.18 \\
+1.59 \\
+0.11 \\
-1.68 \\
-0.80\end{array}$ \\
\hline - & & & & & & & & & $\begin{array}{r}1095.00 \\
\pm 0.34\end{array}$ & \\
\hline
\end{tabular}

${ }^{a}$ Calculated from the measured amounts of nitrite and nitrate, assuming that the absorption of nitrogen oxides proceeded as indicated by eq 3 and 4 .

TABLE 5. Calculation of the heat of combustion of cyanogen from the data of table 3 in which oxygen saturated with water at $0^{\circ}$ $C$ was used for combustion

\begin{tabular}{|c|c|c|c|c|c|c|c|c|c|c|c|c|}
\hline Experiment & $\begin{array}{l}\text { Amount } \\
\text { of NO } \\
\text { formeda }^{\mathrm{a}}\end{array}$ & $\begin{array}{l}\text { Amount } \\
\text { of } \mathrm{NO}_{2} \\
\text { formed }\end{array}$ & $\begin{array}{l}\text { Amount } \\
\text { of } \mathrm{HNO}_{3} \\
\text { formed }^{\mathrm{a}}\end{array}$ & $\begin{array}{l}\text { Amount } \\
\text { of } \mathrm{CO} \\
\text { formed }\end{array}$ & $\begin{array}{c}\text { Correc- } \\
\text { tion } \\
\text { for NO }\end{array}$ & $\begin{array}{l}\text { Correc- } \\
\text { tion } \\
\text { for } \mathrm{NO}_{2}\end{array}$ & $\begin{array}{l}\text { Correc- } \\
\text { tion for } \\
\mathrm{HNO}_{3}\end{array}$ & $\begin{array}{c}\text { Correc- } \\
\text { tion } \\
\text { for } \mathrm{CO}\end{array}$ & $\begin{array}{c}\text { Corrected } \\
\text { reaction } \\
\text { energy }\end{array}$ & $\begin{array}{l}\text { Amount } \\
\text { of } \mathrm{C}_{2} \mathrm{~N}_{2} \\
\text { burned }\end{array}$ & $\begin{array}{l}\text { Heat of } \\
\text { combustion } \\
\text { at } 25^{\circ} \mathrm{C}\end{array}$ & $\begin{array}{l}\text { Deviation } \\
\text { from mean }\end{array}$ \\
\hline $\begin{array}{l}1 \\
2-\ldots \\
3 \\
3 \\
4 \\
5 \\
6 \\
7 \\
7\end{array}$ & $\begin{array}{c}\text { Moles } \\
0.0012632 \\
.0010097 \\
.0010085 \\
.0012577 \\
.0013668 \\
.0013061 \\
.0013424\end{array}$ & $\begin{array}{c}\text { Moles } \\
0.0012632 \\
.0010097 \\
.0010085 \\
.0012577 \\
.0013668 \\
.0013061 \\
.0013424\end{array}$ & $\begin{array}{c}\text { Moles } \\
0.0003488 \\
.0003677 \\
.0002150 \\
.0004051 \\
.0003337 \\
.0004696 \\
.0003398\end{array}$ & $\begin{array}{c}\text { Moles } \\
0.0003540 \\
.0003990 \\
.0005440 \\
.0003876 \\
.0003122 \\
.0003479 \\
.0003108\end{array}$ & $\begin{array}{r}j \\
114.2 \\
91.2 \\
91.1 \\
113.7 \\
123.5 \\
118.0 \\
121.3\end{array}$ & $\begin{array}{l}j \\
42.8 \\
34.2 \\
34.1 \\
42.6 \\
46.3 \\
44.2 \\
45.4\end{array}$ & $\begin{array}{l}j \\
-4.5 \\
-4.7 \\
-2.8 \\
-5.2 \\
-4.3 \\
-6.0 \\
-4.4\end{array}$ & $\begin{array}{c}j \\
100.2 \\
112.9 \\
153.9 \\
109.7 \\
88.3 \\
98.5 \\
88.0\end{array}$ & $\begin{array}{c}j \\
58671.5 \\
58625.3 \\
58486.0 \\
58551.9 \\
58049.1 \\
58877.8 \\
58301.3\end{array}$ & $\begin{array}{c}\text { Moles } \\
0.0534423 \\
.0534864 \\
.0534100 \\
.0533599 \\
.0528789 \\
.0536652 \\
.0531300\end{array}$ & $\begin{array}{l}\text { kj/mole } \\
1097.85 \\
1096.08 \\
1095.04 \\
1097.30 \\
1097.77 \\
1097.13 \\
1097.33\end{array}$ & $\begin{array}{r}k j / m o l e \\
+0.92 \\
-.85 \\
-1.89 \\
+0.37 \\
+.84 \\
+.20 \\
+.40\end{array}$ \\
\hline \multicolumn{12}{|c|}{$\begin{array}{l}\text { Mean } \\
\text { Standard deviation of the mean }\end{array}$} & \\
\hline
\end{tabular}
and 11 .

Calculated from the measured amounts of nitrite and nitrate, assuming that the absorption of nitrogen oxides and nitric acid proceeded as indicated by eq 10

The heat of combustion of cyanogen, taken as the mean of the two series and including a correction of $0.00_{2} \mathrm{kj}$ to adjust the value to the standard state, becomes:

$$
\begin{gathered}
\mathrm{C}_{2} \mathrm{~N}_{2} \quad \text { (cyanogen, gas) }+2 \mathrm{O}_{2} \text { (gas) }=2 \quad \mathrm{CO}_{2} \text { (gas) }+ \\
\mathrm{N}_{2} \text { (gas), } \\
\begin{array}{c}
\Delta H c^{\circ}\left(25^{\circ} \mathrm{C}\right)=-1095.97 \pm 1.80 \mathrm{kj} / \mathrm{mole} \\
=-261.94 \pm 0.43 \mathrm{kcal} / \mathrm{mole} .
\end{array}
\end{gathered}
$$

The assigned uncertainty is the estimated over-all uncertainty considering the uncertainty in the exact products of combustion, in the amount of water carried through the calorimeter by the oxygen, in the electrical energy equivalent, and in other factors considered to be of lesser importance.

Combination of this value with the value for the heat of formation of carbon dioxide $\Delta H^{\circ}=-393.513$ $\mathrm{kj} / \mathrm{mole}[2]$ yields the heat of formation of cyanogen

$2 \mathrm{C}(c$, graphite $)+\mathrm{N}_{2}$ (gas) $=\mathrm{C}_{2} \mathrm{~N}_{2}$ (cyanogen, gas),

$$
\begin{aligned}
\Delta H f^{\circ}\left(25^{\circ} \mathrm{C}\right) & =308.94 \pm 1.80 \mathrm{kj} / \mathrm{mole} \\
& =73.84 \pm 0.43 \mathrm{kcal} / \mathrm{mole} .
\end{aligned}
$$

The encouragement and assistance of M. M. Haring, formerly of the University of Maryland, and

\begin{tabular}{|c|c|c|}
\hline Investigation & $\begin{array}{c}\text { Year } \\
\text { reported }\end{array}$ & $-\Delta H c$ \\
\hline $\begin{array}{l}\text { Dulong [17] } \\
\text { Berthelot [18] } \\
\text { Thomsen [19] } \\
\text { von Wartenberg \& Schutza } \\
\text { [12] } \\
\text { McNorris \& Badger [20] } \\
\text { Present }\end{array}$ & $\begin{array}{l}1838 \\
1879 \\
1886 \\
\\
1933 \\
1933 \\
1950\end{array}$ & $\begin{array}{l}\quad k c a l / \text { mole } \\
275 \\
264 \\
259.4 \\
\\
261.3 \\
251.4 \\
261.94 \pm 0.43\end{array}$ \\
\hline
\end{tabular}
of F. D. Rossini, who directed this work, are gratefully acknowledged.

The heat of combustion as determined in this investigation is compared with the following existing data: 


\section{References}

[1] E. F. Mueller and F. D. Rossini, Am. J. Phys. 12, 1 (1944).

[2] Selected values of chemical thermodynamic properties, NBS Circular C500 (1951).

[3] G. P. Baxter, M. Guichard, and R. Whytlaw-Gray, J. Am. Chem. Soc. 69, 73 (1947).

[4] F. D. Rossini, BS J. Research 6, 1 (1931) RP259.

[5] F. D. Rossini, Chem. Rev. 18, 233 (1936).

[6] F. D. Rossini and J. W. Knowlton, J. Research NBS 19, 249 (1937) RP1024.

[7] R. P. Cook and P. L. Robinson, J. Chem. Soc. 1935 1001.

[8, M. Shepherd, BS J. Research 12, 185 (1934) RP643.

[9] R. A. Ruehrwein and W. F. Giauque, J. Am. Chem. Soc. 61, 2940 (1939).

[10] J. W. Mellor, A Comprehensive treatise on inorganic and theoretical chemistry VIII, p. 429-30 (Longmans, Green, and Co., London, 1922).
[11] F. D. Rossini, BS J. Research 12, 735 (1934) RP686.

[12] H. von Wartenberg and H. Schutza, Z. physik. Chem. A164, 386 (1936).

[13] Int. Crit. Tables V, 80, 82 (McGraw-Hill Book Co., New York, N. Y. 1929).

[14] F. H. Verhoek and F. Daniels, J. Am. Chem. Soc. 53, 1250 (1931).

[15] W. F. Giauque and J. D. Kemp, J. Chem. Phys. 6, 40 (1938).

[16] C. L. Burdick and E. S. Freed, J. Am. Chem. Soc. 43, 518 (1921).

[17] F. L. Dulong, Compt. rend. 7, 871 (1838).

[18] M. Berthelot, Ann. chim. phys. [5] 18, 345 (1879).

[19] J. Thomsen, Thermochemische Untersuchungen IV (Barth, Leipzig, 1886).

[20] J. MeNorris and R. M. Badger, J. Am. Chem. Soc. 55, $1952(1933)$

Washington, October 23, 1950. 